\title{
International reference pricing for prescription drugs: a landscape analysis
}

\author{
Leah Z Rand, DPhil, and Aaron S Kesselheim, MD, JD, MPH
}

\section{SUMMARY}

During the Trump administration, members of Congress and the administration proposed the introduction of international reference pricing (IRP) to Medicare in order to reduce US drug spending by benchmarking prices to those in other countries. Many other countries currently use IRP.
We examined how US policy proposals compare with the implementation of IRP in the countries that would be referenced by the United States. Nearly two-thirds of comparator countries use IRP but also use other price negotiation strategies. The congressional proposal was most like the approach used by other countries, while the Trump administration's proposals took an uncommon approach to IRP by not adopting additional pricing strategies.
Because the United States pays the highest prices in the world for brand-name prescription drugs, lawmakers have considered limiting US drug prices based on prices in a "basket" of economically similar countries, a strategy known as international reference pricing (IRP). Proposed policies take 2 different approaches to IRP: the Elijah Cummings Lower Drug Costs Now Act (HR 3), which passed the House of Representatives in December 2019 , set a maximum negotiated price at $120 \%$ of the basket average, required further negotiation, and offered those prices to the private market. ${ }^{1}$ The Congressional Budget Office estimated that IRP and price negotiation would lower direct Medicare spending during $2020-2029$ by $\$ 448$ billion. ${ }^{2}$ The Cummings bill was never given a vote in the Senate in 2020, but a version of it is likely to be reintroduced in 2021.

By contrast, an executive order issued in 2020 by former President Trump and an interim final rule from the Centers for Medicare \& Medicaid Services (CMS) took a "most favored nation" approach, selecting the lowest price from the basket as the maximum reimbursable amount and applying it only to Medicare.,4 CMS estimated $\$ 85.5$ billion in savings over 7 years from applying the most favored nation model to Medicare Part B. ${ }^{4}$ The most favored nation approach and its implementation through the CMS rule have raised concerns among prescribers that patient access will be significantly restricted and negatively impact care and outcomes. ${ }^{5}$ Following a court injunction, neither the executive order nor interim rule have been implemented. ${ }^{6}$

Since the current Congress and new presidential administration may also seek to incorporate IRP into new pharmaceutical pricing reform, we sought to examine how other countries use IRP to help inform US policy choices.

\section{Author affiliations \\ Leah Z Rand, DPhil, Program on \\ Regulation, Therapeutics, and Law, Division of Pharmacoepidemiology and Pharmacoeconomics, Brigham and Women's Hospital, Boston, MA. Aaron S Kesselheim, MD, JD, MPH, Harvard Medical School, and Program on Regulation, Therapeutics, and Law, Division of Pharmacoepidemiology and Pharmacoeconomics, Brigham and Women's Hospital, Boston, MA.}

AUTHOR CORRESPONDENCE: Leah Z Rand, 857.307.3811; lzrand@bwh.harvard.edu

J Manag Care Spec Pharm. 2021;27(9):1309-13

Copyright $\odot 2021$, Academy of Managed Care Pharmacy. All rights reserved.

\section{International Implementation of IRP}

Many countries use IRP to negotiate prices, so we sought to understand how the 2 most prominent recent US proposals compared with the implementation of IRP in the countries that would be referenced by the United States. The Cummings bill referenced 6 countries: Australia, Canada, France, Germany, Japan, and the United Kingdom. ${ }^{1}$ The executive order covered member states of the Organisation for Economic Co-operation and Development (OECD) with a US-comparable gross 


\begin{tabular}{|c|c|c|c|c|c|c|c|c|}
\hline Country & $\begin{array}{c}\text { \% GDP } \\
\text { on drug } \\
\text { spending }\end{array}$ & $\begin{array}{l}\text { \% US } \\
\text { GDP per } \\
\text { capitab }^{\text {b }}\end{array}$ & $\begin{array}{l}\text { IRP is } \\
\text { primary } \\
\text { pricing } \\
\text { tool }\end{array}$ & $\begin{array}{c}\text { Countries in } \\
\text { basket, } n\end{array}$ & $\begin{array}{c}\text { Covered } \\
\text { lives } \\
\text { (millions)c }\end{array}$ & $\begin{array}{c}\text { IRP applied } \\
\text { to which drugs }\end{array}$ & $\begin{array}{l}\text { How the basket } \\
\text { is referenced }\end{array}$ & $\begin{array}{c}\text { Other } \\
\text { methods used }\end{array}$ \\
\hline Japan* & 1.97 & 61.82 & No & 4 & 126.40 & $\begin{array}{l}\text { Brand named and } \\
\text { reimbursede }\end{array}$ & $\begin{array}{c}\text { Range } 75 \%-125 \% \\
\text { of average }\end{array}$ & $\begin{array}{l}\text { Cost basisf } \\
\text { DTRPg, HTA }\end{array}$ \\
\hline $\begin{array}{l}\text { United States: } \\
\text { HR } 3\end{array}$ & \multirow{3}{*}{1.95} & \multirow{3}{*}{100.00} & No & 6 & \multirow{3}{*}{62.98} & $\begin{array}{c}250 \text { most expensive, } \\
\text { brand-name, single source } \\
\text { drugs for Medicare }\end{array}$ & Average & HTA, cost basis \\
\hline $\begin{array}{l}\text { United States: } \\
\text { executive order }\end{array}$ & & & Yes & likely 19 & & $\begin{array}{l}\text { All drugs in } \\
\text { Medicare Parts B and D }\end{array}$ & Lowest & $\mathrm{N} / \mathrm{A}$ \\
\hline $\begin{array}{l}\text { United States: } \\
\text { CMS interim } \\
\text { final rule }\end{array}$ & & & Yes & likely 19 & & 50 Medicare Part B drugs & Lowest & $\mathrm{N} / \mathrm{A}$ \\
\hline Canada* & 1.75 & 70.94 & No & $\begin{array}{l}7(11 \text { as of } \\
\text { mid-2021) }\end{array}$ & 37.06 & Brand name & Median & HTA, DTRP \\
\hline Germany* & 1.63 & 71.04 & No & 15 & 82.91 & $\begin{array}{l}\text { Brand name and } \\
\text { reimbursed }\end{array}$ & Weighted average & $\begin{array}{l}\text { HTA, DTRP, } \\
\text { informal IRP }\end{array}$ \\
\hline Belgium & 1.51 & 70.82 & No & 27 & 11.40 & Brand name & Average & DTRP \\
\hline France $^{\star}$ & 1.47 & 62.12 & No & 4 & 66.94 & $\begin{array}{l}\text { Brand name and } \\
\text { reimbursed }\end{array}$ & $\begin{array}{c}\text { Range between } \\
\text { highest and lowest }\end{array}$ & $\begin{array}{c}\text { HTA, DTRP, spending } \\
\text { caps, 'other }\end{array}$ \\
\hline Switzerland & 1.46 & 125.90 & Yes $^{k}$ & 9 & 8.513 & On-patent & Average & HTA, DTRP \\
\hline Australia*l & 1.27 & 84.32 & No & 0 & 24.99 & N/A & N/A & HTA, DTRP, cost basis \\
\hline Austria & 1.24 & 77.21 & Yes & 27 & 8.838 & Brand name & $\leq$ Average & Other $^{m}$ \\
\hline $\begin{array}{l}\text { United } \\
\text { Kingdom* }\end{array}$ & 1.23 & 64.96 & No & 0 & 66.44 & $\mathrm{~N} / \mathrm{A}$ & $\mathrm{N} / \mathrm{A}$ & $\begin{array}{l}\text { HTA, spending } \\
\text { caps, other }\end{array}$ \\
\hline Finland & 1.12 & 74.77 & No & 29 & 5.516 & Brand name & Average $^{n}$ & HTA \\
\hline Sweden & 1.07 & 79.26 & No & 0 & 10.18 & $\mathrm{~N} / \mathrm{A}$ & N/A & HTA \\
\hline Israel & 0.94 & 67.02 & No & 7 & 8.873 & All & Average & Other \\
\hline Iceland & 0.92 & 102.80 & No & 4 & 0.353 & Brand name & $\begin{array}{c}\text { Average } \\
\text { (outpatient) or } \\
\text { lowest (inpatient) }\end{array}$ & HTA, DTRP \\
\hline
\end{tabular}

domestic product (GDP) per capita, which the CMS rule specified as at least $60 \%$ of the United States. ${ }^{3,4}$ OECD members with a GDP per capita $60 \%$ or greater of the United States were the 6 countries referenced in the Cummings bill and Austria, Belgium, Denmark, Finland, Iceland, Ireland, Israel, Luxembourg, the Netherlands, New Zealand, Norway, Sweden, and Switzerland.

To describe the characteristics of IRP policies, we searched peer-reviewed publications and grey literature reports to determine if and how IRP is implemented, basket sizes, referenced countries, percentage of GDP spending on drugs, and other price negotiation policies in place. ${ }^{7-15}$

Of the 19 countries, 15 used IRP. Ten used IRP to supplement health technology assessment, domestic therapeutic reference pricing, and other agreements reached through direct negotiation with manufacturers. The remaining 5 countries used IRP as the primary approach to negotiate prices, of which 3 were in the bottom third for spending on drugs but also had higher GDP per capita and substantially smaller populations than the United States. The median basket size was 7 countries (range $=1-29$ ). The most common approach was to use the average price among basket countries $(n=9)$, whereas 1 country used the lowest. The United Kingdom was the most frequently referenced country by the sample $(n=13)$, followed by Germany $(n=12)$. All 15 countries employing IRP used ex-factory (list) prices for IRP exclusively for on-patent, brand-name drugs, with generics separately regulated by non-IRP pricing procedures (Table 1). 


\begin{tabular}{|c|c|c|c|c|c|c|c|c|}
\hline Country & $\begin{array}{c}\text { \% GDP } \\
\text { on drug } \\
\text { spending }\end{array}$ & $\begin{array}{l}\text { \% US } \\
\text { GDP per } \\
\text { capitab }^{\mathrm{b}}\end{array}$ & $\begin{array}{l}\text { IRP is } \\
\text { primary } \\
\text { pricing } \\
\text { tool }\end{array}$ & $\begin{array}{c}\text { Countries in } \\
\text { basket, } n\end{array}$ & $\begin{array}{c}\text { Covered } \\
\text { lives } \\
\text { (millions) }\end{array}$ & $\begin{array}{l}\text { IRP applied } \\
\text { to which drugs }\end{array}$ & $\begin{array}{l}\text { How the basket } \\
\text { is referenced }\end{array}$ & $\begin{array}{c}\text { Other } \\
\text { methods used }\end{array}$ \\
\hline Ireland & 0.86 & 120.80 & Yes & 14 & 4.857 & $\begin{array}{l}\text { Brand name and } \\
\text { reimbursed }\end{array}$ & Average & HTA, DTRP \\
\hline Norway & 0.75 & 115.80 & Yes & 9 & 5.312 & $\begin{array}{c}\text { Outpatient } \\
\text { brand name }\end{array}$ & Average of 3 lowest & $\mathrm{N} / \mathrm{A}$ \\
\hline Netherlands & 0.74 & 80.54 & No & 4 & 17.23 & Brand name & Average & HTA, DTRP \\
\hline Denmark & 0.65 & 91.87 & No & 9 & 5.790 & Inpatient brand name & Average & HTA, DTRP \\
\hline New Zealand & - & 64.63 & No & 0 & 4.886 & $\mathrm{~N} / \mathrm{A}$ & N/A & HTA, DTRP \\
\hline Luxembourg & 0.60 & 176.15 & Yes & $1^{\circ}$ & 0.608 & Brand name & N/A & data missing \\
\hline
\end{tabular}

Note: Blue shaded rows are countries that do not use IRP; those marked with * are named in the Cummings bill.

a2019 data from https://data.oecd.org/healthres/pharmaceutical-spending.htm\#indicator-chart. Data for New Zealand is missing; it is positioned by percentage of GDP on health spending. ${ }^{23}$

b2019 GDP per capita from https://data.worldbank.org/indicator/NY.GDP.PCAP.CD?most_recent_value desC=true.

'Country population except for United States. Data since 2018 from https://data.oecd.org/pop/population.htm. US data (October 2019) is total Medicare enrollment (https://www.cms.gov/Research-Statistics-Data-and-Systems/Statistics-Trends-and-Reports/CMSProgramStatistics/Dashboard).

"Brand-name" drugs encompass those that do not face competition and usually are still under patent protection. The countries in the table have separate regulations for pricing generics.

${ }^{e}$ Reimbursed medications are those included on a positive reimbursement list and paid for (in part or in full) by national insurance programs.

'Cost-basis pricing considers the costs to manufacturers to produce the medicine and may include research and development costs. ${ }^{24}$

${ }^{9} D T R P$ is the practice of setting prices for new drugs to be the same as those for clinically similar drugs unless additional effectiveness can be proven, in which case HTA is often used to determine the extent of additional benefit and therefore the appropriate price. Some countries use periodic price competition to set the maximum price or reimbursement rates for a class of drugs, including on-patent, branded ones.

"HTA is broadly applied here to cover pricing approaches based on comparative effectiveness. Such approaches are sometimes called "value-based pricing." 'Canada will be dropping the United States and Switzerland from its current basket and adding 6 countries in July 2021. This table reflects the 2020-2021 basket (https://www.canada.ca/en/patented-medicine-prices-review/services/legislation/about-guidelines/guidelines.html).

iHealth system spending on pharmaceuticals is capped and manufacturers are responsible for paying back overspend.

${ }^{k}$ IRP is used to weight two-thirds of the price calculation. ${ }^{7}$

"Until 2014, prices were referenced to "reasonably comparable overseas countries," probably New Zealand and the United Kingdom (https://www.pbs.gov.au/info/ industry/pricing/pbs-items/pba-policies-procedures).

"'Other" is used here as an inclusive category for discount agreements that may be negotiated with manufacturers, such as risk-sharing agreements, volume-based agreements, managed entry agreements, or other discounts and rebates.

'Though IRP information is collected, there is limited information on its use, and it appears to inform negotiations rather than be regulated as a price ceiling.?

'Luxembourg references to the country of origin of the drug.

CMS =Centers for Medicare \& Medicaid Services; DTRP=domestic therapeutic reference pricing; GDP=gross domestic product; HTA=health technology assessment; $I R P=$ international reference pricing; $N / A=$ not available.

Among the smaller cohort of 6 countries named in the Cummings bill, all primarily used health technology assessment to negotiate prices, with 4-excluding Australia and the United Kingdom-using IRP as a supplement, for example, to set a range that the price should be in or to compare prices when there are not clinically similar drugs already available. These 4 countries have small baskets (median $=5.5$, range $=4-15$ ), all reference UK prices, and 2 (Japan and Canada) reference US prices. Canada will remove the United States from its basket in July 2021.

\section{Policy Implications}

Most high-income countries use IRP to negotiate drug prices, typically complementing other strategies-such as health technology assessment for value-based pricing-that aim to align prices with the health impact of new drugs. For example, Switzerland uses a strong, formal IRP approach that calculates a reimbursement price that is weighted by twothirds of the average IRP price and one-third by comparison with Swiss prices for comparator drugs.? By contrast, the German informal IRP approach limits IRP use to instances 
when agreement is not reached with the manufacturer on a reimbursement price based on health technology assessment. ${ }^{16}$ The Cummings bill was most similar to the majority of sampled countries because IRP is used to supplement other methods. In addition, the Cummings bill used a small reference basket, identified an average price based on the basket countries and applied to brand-name drugs.

By contrast, the most favored nation approach taken by CMS and the executive order benchmarked to the lowest basket price and did not include additional methods for negotiation. Few countries adopt an approach using IRP alone to price drugs. A primary reason is that only list prices are available for IRP. Because most countries negotiate confidential discounts off list prices, relying exclusively on IRP would overestimate actual prices. Also, there are economic concerns about the effects of strictly benchmarking to other countries' list prices and how list prices may be manipulated to minimize price reductions in the United States or elsewhere. ${ }^{17,18}$ Additional concerns with an IRP-only approach include missing data and the heterogeneity of available pricing information, unaffordability of IRP prices, and the introduction of country-specific formulations to make IRP more difficult. ${ }^{19,20}$ Finally, the CMS rule applied narrowly to 50 drugs, while most other countries using IRP broadly apply it to brand-name drugs.

If the United States implements IRP, US prices will become sensitive to price changes in the referenced countries and the referenced countries' basket of countries. For example, the United Kingdom is the most influential country for IRP schemes because most countries reference its prices and it does not use IRP. Political changes, such as Brexit, and currency fluctuations affect drug prices and can have ripple effects because of price cross-referencing between countries. ${ }^{21,22}$ Using an average price provides some insulation from fluctuations. Thus, our results show that if brand-name manufacturers raise list prices in other countries, it would blunt the impact of IRP and especially the most favored nations approach.

The future of IRP under the Biden administration and current Congress is uncertain. Learning from the example of its comparator countries, if the United States adopts an IRP policy, it should be one that uses IRP to anchor price negotiations and complements it with other reimbursement strategies, such as value assessments.

\section{DISCLOSURES}

This work was supported by Arnold Ventures, which provided overall funding but was not involved in conception, design, or conduct of this work. Kesselheim provides guidance to the Massachusetts Health Policy Commission on its prescription drug price review process under a contract to Brigham and Women's Hospital but does not receive personal funding for this work. Rand has nothing to disclose.

\section{ACKNOWLEDGMENTS}

Changwon C. Lee, AB, Harvard Medical School, assisted with data collection.

\section{REFERENCES}

1. Elijah E. Cummings Lower Drug Costs Now Act. HR 3, 116th Congress (2019). Accessed July 14, 2020. https://www. congress.gov/bill/116th-congress/ $\underline{\text { house-bill } / 3}$

2. Congressional Budget Office. Budgetary effects of H.R. 3, the Elijah E. Cummings Lower Drug Costs Now Act. Letter. December 10, 2019. Accessed July 15, 2021. https://www.cbo.gov/system/files/201912/hr3 complete.pdf
3. Executive Office of the President. Lowering drug prices by putting America first. Executive Order 13948. September 13, 2020. 85 FR 59649-59650. Accessed July 15, 2021. https://www.govinfo.gov/ content/pkg/FR-2020-09-23/pdf/202021129.pdf

4. Centers for Medicare \& Medicaid Services, Department of Health and Human Services. Most Favored Nation (MFN) Model. November 27, 2020. 85 FR 76180. Accessed December 4, 2020. https://www.govinfo.gov/content/pkg/ FR-2020-11-27/pdf/2020-26037.pdf

5. Community Oncology Alliance. Oncologists sue to stop "dangerous and unlawful" most favored nation drug pricing scheme [press release]. December 11, 2020. Accessed July 14, 2021. https:// communityoncology.org/oncologists-sueto-stop-dangerous-and-unlawful-mostfavored-nation-drug-pricing-scheme/

6. Centers for Medicare \& Medicaid Services. Most Favored Nation Model. 2021. Updated February 4, 2021.

Accessed April 13, 2021. https://innovation.cms.gov/innovation-models/ most-favored-nation-model

7. Sjöberg D, Uddén A, Hortlund P, et al. International price comparison 2018: an analysis of Swedish pharmaceutical prices and volumes relative to 19 other European countries. Dental and Pharmaceutical Benefits Agency. December 2018. Accessed July 15, 2021. https://www. tlv.se/download/18.7ff0047816a01500 64d26514/1554902942161/international_ price_comparison_2018.pdf

8. Vogler S, Zimmerman N, Haasis MA. PPRI Report 2018: Pharmaceutical pricing and reimbursement policies in 47 PPRI network member countries. WHO Collaborating Centre for Pricing and Reimbursement Policies. Gesundheit Österreich GmbH (GÖG/Austrian National Public Health Institute), Vienna. October 2019. Accessed July 21, 2021. https:// ppri.goeg.at/sites/ppri.goeg.at/files/ inline-files/PPRI\%20Report2018 2nd edition_final.pdf 
9. Verghese NR, Barrenetxea J, Bhargava Y, Agrawal S, Finkelstein EA. Government pharmaceutical pricing strategies in the Asia-Pacific region: an overview. J Mark Access Health Policy. 2019;7(1):1601060.

10. Kanavos P, Fontrier A-M, Gill J, Kyriopoulos D. The Implementation of External Reference Pricing within and across Country Borders. London School of Economics; 2017.

11. Patented Medicine Prices Review Board. June 2020 PMPRB Draft Guidelines. July 31, 2020. Updated August 5, 2020. Accessed October 19, 2020. https://www.als.ca/blogs/ june-2020-pmprb-draft-guidelines /

12. Vogler S, Lepuschütz L, Schneider P, Stühlinger V. Study on Enhanced CrossCountry Coordination in the Area of Pharmaceutical Product Pricing. Publications Office of the European Union; 2015.

13. Irish Pharmaceutical Healthcare Association. Framework agreement on the supply and pricing of medicines. July 2016. Accessed September 21, 2020. https://www.ipha.ie/about-us/our-role/ agreement-on-the-supply-of-medicines/

14. Norwegian Medicines Agency. Guidelines for price setting in Norway. October 4, 2018. Accessed July 21, 2021. https://legemiddelverket.no/english/ public-funding-and-pricing/maximumprice\#determination-of-maximum-price
15. Wenzl M, Paris V. Pharmaceutical reimbursement and pricing in Germany. OECD. June 2018. Accessed July 15, 2021. https://www.oecd.org/health/ health-systems/PharmaceuticalReimbursement-and-Pricing-in-Germany. pdf

16. Gemeinsamer Bundesausschuss. The benefit assessment of medicinal products in accordance with the German Social Code, Book Five (SGB V), section 35a. Accessed October 21, 2019. https://www.g-ba.de/english/ benefitassessment/

17. Gavulie KA, Pelletier-Fleury N, Dusetzina SB. Peer Comparisons for drug price setting: why international reference pricing may not provide optimal prices. JAMA Health Forum. 20201(2):e200105. doi: 10.1001/jamahealthforum.2020.0105

18. Rand LZ, Kesselheim AS. International reference pricing for prescription drugs in the United States: administrative limitations and collateral effects. Value Health. 2021;24(4):473-76. doi: 10.1016/j. jval.2020.11.009

19. World Health Organization. WHO Guideline on Country Pharmaceutical Pricing Policies. 2d ed. World Health Organization; 2020.
20. Oğuzhan GlE. Impact of the international reference pricing on pharmaceutical market access. In: Kockaya G, Wertheimer A, eds. Pharmaceutical Access in Developed Markets. SEEd; 2018.

21. Foundation for Pharmaceutical Statistics (SFK). Facts and figures 2017: on pharmaceutical care in the Netherlands in 2016. December 2017. Accessed September 21, 2020. https://www.sfk.nl/english/ facts-and-figures-2017

22. Stargardt T, Schreyogg J. Impact of cross-reference pricing on pharmaceutical prices: manufacturers' pricing strategies and price regulation. Appl Health Econ Health Policy. 2006;5(4):235-47.

23. OECD. Pharmaceutical spending (indicator). 2020. Accessed December 7, 2020. https://doi.org/10.1787/998febf6-en

24. Shiroiwa T, Fukuda T, Ikeda S, Takura T. New decision-making processes for the pricing of health technologies in Japan: the FY 2016/2017 pilot phase for the introduction of economic evaluations. Health Policy. 2017;121(8):836-41. 